\title{
Fatwa antara Makharij Fiqhiyah dan Market Needs: Eklektisisme Pragmatis di balik Fatwa DSN MUI di Indonesia
}

\author{
Muhammad Sholihin \\ Institut Agama Islam Negeri Curup \\ sholihin@iaincurup.ac.id

\begin{tabular}{l|l|l}
\hline Received: 15 Maret 2020 & Revised: 20 April 2020 & Approved: 04 Mei 2020
\end{tabular}

\begin{abstract}
This study seeks to explore the possibility of implementing eclecticpragmatic reasoning in the DSN-MUI fatwa on Sharia Banking Products. By applying the Ahmed Fekry Ibrahim study model when exploring the eclectic-pragmatic tradition of Islamic law. This study finally succeeded in introducing a thesis that the DSN-MUI fatwa, especially related to Islamic banking products, is full of eclectic-pragmatic reasoning. This is also expected to be the novelty of this study. Because previous studies, such as those conducted by Ahmed Fekry Ibrahim did not specifically discuss the eclecticism of Islamic law on the fatwa products of the Indonesian Scholar Council related to Islamic banking products. This can be identified from two things, namely: First, the eclectic-pragmatic reasoning of the DSN MUI Fatwa on Islamic banking products can be traced from the selection of legal arguments that are consistent in primary arguments, but flexible in choosing secondary arguments - the views of cleric. Second, the principle of protection of corporate needs, in this case encouraging the banking industry to respond to market needs, so that fatwa are made in the framework of these interests.
\end{abstract}

Keywords: Eclectic-Pragmatics, Makharij Fiqhiyyah, Market Needs, and Utilitarianism.

\begin{abstract}
Abstrak
Kajian ini berusaha menelusuri bagaimana implementasi nalar eklektisisme-pragmatis pada fatwa DSN-MUI tentang Produk Perbankan Syariah. Dengan menerapkan model kajian Ahmed Fekry Ibrahim ketika menelusuri tradisi eklektisisme-pragmatis hukum Islam. Kajian ini akhirnya berhasil memperkenalkan satu tesis bahwa fatwa DSN-MUI, terutama terkait produk perbankan syariah, sarat akan penalaran eklektisisme-pragmatis. Hal tersebut sekaligus diharapkan menjadi novelty kajian ini. Karena penelitian terdahulu, seperti yang dilakukan oleh Ahmed
\end{abstract}


Fekry Ibrahim tidak secara khusus membahas eklektisisme hukum Islam pada produk fatwa Majelis Ulama Indonesia terkait produk perbankan syariah. Ini dapat diidentifikasi dari dua hal, yakni: Pertama, penalaran eklektisisme-pragmatis pada Fatwa DSN MUI tentang produk perbankan syariah dapat dilacak dari pemilihan dalil hukum yang bersifat konsisten pada dalil-dalil primer, namun bersifat fleksibel dalam memilih dalil-dalil sekunder-pandangan para ulama. Kedua, adanya prinsip proteksi terhadap kebutuhan korporat, dalam hal ini mendorong industri perbankan merespon kebutuhan pasar, sehingga fatwa dibuat dalam rangka kepentingan tersebut.

Kata Kunci: Eklektisisme-Pragmatis, Fatwa, Makharij Fiqhiyyah, Market Needs, dan Utilitarianisme.

\section{Pendahuluan}

Setiap fatwa dan produk istinbath hukum yang diusahakan oleh para ulama, dan mujtahid, niscaya mengandung nalar. Hal ini sejalan dengan fungsi dan konsep fatwa itu sendiri, dimana fatwa atau فتوى berasal dari bahasa Arab. Dalam hal ini, Ibn Mandzur mendefinisikan fatwa secara etimologi sebagai "aftahu fi al-amr abanahu labu", atau mengeluarkan pendapat terhadap sesuatu persoalan disertai penjelasan. Sedang terminologi fatwa, merujuk pada Abdul Karim Zaidan, sebagai sesuatu yang mengandung unsur-unsur seperti mustafti (objek fatwa), mufti (orang yang berfatwa), ifta' (proses berfatwa); dan hukum (bukm). Sedangkan Imam Syathibi menjelaskan bahwa: "mufti dalam masyarakat menempati posisi Nabi Muhammad saw." Artinya, ia berfungsi dan memikul peran menjelaskan persoalan hukum dan menetapkan hukum yang dihadapi oleh umat ${ }^{1}$. Konsep yang diajukan oleh para ulama ini menegaskan bahwa fatwa adalah produk dari hasil ijtihad para ulama yang qualified.

Dalam menghasilkan sebuah fatwa, ulama menerapkan berbagai metode, khususnya ushul fiqh. Hal ini sejalan dengan konsep ijtihad itu sendiri, dimana AlRazi mendefinisikan ijtihad sebagai usaha yang kuat dalam menghasilkan pendapat terhadap sesuatu yang tidak tercela. Sedangkan Abu Hamid Al-Ghazali mendefinisikan fatwa sebagai usaha yang kuat dalam menghasilkan sesuatu dan usaha tersebut sudah sangat maksimal. Lebih fokus, Al-Zarkasy mendefinisikan ijtihad sebagai usaha yang sungguh untuk menghasilkan hukum syar'i dengan metode al-istinbath. ${ }^{2}$ Ijtihad ini dilakukan oleh para ulama, dan kemudian menghasilkan sebuah fatwa, sesungguhnya ditujukan untuk mendapatkan berkah dari Allah Swt, dan sepenuhnya diarahkan untuk menyelesaikan persoalan yang dihadapi oleh umat. Artinya, fatwa diproduksi dan dihasilkan semata untuk motif transendental, guna meraih pahala dari Allah Swt. Kendati demikian,

\footnotetext{
${ }^{1}$ Ustman bin Abdurrahman, Adb Al-Mufti Wa Mustafti (Mosul: Maktabah Al-Ulm wa Al-Hukm, 1986), h. 23.

${ }^{2}$ Ustman bin Abdurrahman, Adb Al-Mufti Wa Mustafti.
} 
seiring perkembangan persoalan yang dihadapi oleh umat, fatwa yang dihasilkan oleh para ulama, khususnya Majelis Ulama di dunia Islam, tidak terlepas dari dorongan yang lebih pragmatis. Misalnya, karena adanya permintaan pasar oleh industri keuangan.

Ahmed Fekry Ibrahim mengidentifikasi dengan baik adanya nilai pragmatisme dalam fatwa yang diproduksi oleh ulama. Fakta ini tidak saja ia temukan pada fatwa kontemporer, tetapi juga sudah akarnya pada fatwa yang termaktub dalam berbagai kitab babon yang ditulis oleh imam mazhab, dan ulama tabi'in. Pragmatisme ini diidentifikasi dari adanya nalar hukum yang mengakomodasi nalar-nalar modernisme yang didasarkan pada kesetaraan warga negara dan nuclear family. Selain itu, indikator adanya pragmatisme dalam fatwa adanya nalar hukum yang mempertimbangkan dispensasi hukum, atau tattabbu' al-rukhas. ${ }^{3}$ Sementara pragmatisme sendiri dihubungkan pula oleh Ahmed Fekry Ibrahim dengan eklektisisme. Hal ini dapat diidentifikasi dari gerakan reformasi hukum Islam yang dibangun oleh sarjana hukum Islam reformis yang memahami doktrin hukum Islam, penafsiran hukum dan hukum sebagai produk yang mendiskriminasikan perempuan dan kelompok minoritas. ${ }^{4}$ Kesimpulan ini dibangun dari penerapan term yang secara kuat berkorelasi dengan pragmatisme hukum dalam tradisi Islam seperti tattabbu' al-rukhas, atau takbayyur; selain itu juga ada talfiq, dimana dua opini hukum dikombinasikan dalam transaksi legal.

Secara khusus Ahmed Fekry Ibrahim memaknai konsep pragmatic dan beberapa derivasinya seperti pragmatist atau darura-pragmatist merupakan posisi sederhana para fuqaha' dan tidak merujuk pada author's weltanschaunng. Ada banyak ulama dan fuqaha' yang menggunakan nalar pragmatisme ini. Misalnya Al-Subki (d.673/1284) dan Al-Zarkasyi (d.794/1392), keduanya kerapkali menerapkan pendekatan pragmatis terkait pluralisme hukum, namun pendekatan non-pragmatic terhadap isu lainnya. Sementara itu, Al-Ghazali (d.505/1111), Al-Syathibi (d.790/1388), keduanya terkenal penentang teori pragmatis-ekletisisme. Keduanya lebih mengedepankan teori kemaslahatan publik atau maslaha. ${ }^{5}$ Namun, pendekatan pragmatisme menjadi hal yang penting dan populer tatkala menghadapi persoalan baru yang muncul di tengah masyarakat. Karena itu, secara tegas pendekatan pragmatisme di artikulasi oleh Al-Juwayni (d.478/1085) dan Al-Suyuthi (d.911/1505), keduanya seringkali menggunakan nalar tatabbu' alrukhas dan tariih dalam memproduksi fatwa hukum. ${ }^{6}$ Ini pula yang menjadi fondasi untuk memahami pendekatan pragmatisme hukum yang pada beberapa kasus terkait fatwa kontemporer, terutama berhubungan dengan fatwa perbankan syariah, cenderung diterapkan dan dijadikan nalar hukum.

3 Ahmed Fekry Ibrahim, Pragmatism in Islamic Law: A Social and Intellectual History (New York: Syracuse University Press, 2015), h. 2.

${ }^{4}$ Ibrahim, Pragmatism in Islamic Law: A Social and Intellectual History.

${ }^{5}$ Ibrahim.

${ }^{6}$ Ibrahim. 
Selain konsep yang ditawarkan oleh Ahmed Fekry Ibrahim, dalam memahami nalar pragmatisme hukum melalui aplikasi metode tattabbu' al-rukhas dan tariih, yang kemudian dielaborasi lebih detail oleh Al-Suyuthi dengan memperhatikan nalar religious atau amr dini, nalar duniawi atau amr duniawi, atau nalar arbitrase atau mujaraddan 'an al-qasd. Perlu juga memperhatikan nalar hukum yang tumbuh sebagai respon terhadap kondisi politik, ekonomi, budaya dan sosial. Dalam konteks inilah kemudian pragmatisme fatwa terkait Bank Syariah oleh DSN MUI, penting dipahami. Sejauh mana nalar pragmatisme diterapkan pada fatwa DSN MUI terkait produk bank syariah di Indonesia.

Argumentasi yang dapat diajukan mengapa fatwa DSN MUI dihubungkan dengan nalar pragmatisme, yakni: Pertama, adanya keyakinan para ulama pada Institusi MUI bahwa fungsi ulama di Indonesia adalah agen dari perubahan sosial yang berorientasi untuk meningkatkan perbaikan atau islabiyyah dalam tatanan sosial-ekonomi, terutama dalam industri keuangan. ${ }^{7}$ Ini bermakna bahwa ulama yang tergabung dalam Majelis Ulama Indonesia (MUI), menjalankan beberapa fungsi-fungsi yang lebih luas. Seperti mengawal bagi umat Islam, pemberi edukasi dan pembimbing umat, dan memberikan solusi terhadap masalah keagamaan. Hal ini menegaskan bahwa tugas Majelis Ulama Indonesia bersifat idealis dan pragmatis sekaligus. Idealis karena menjalankan fungsi pengetahuan, sementara pragmatis karena menjalankan fungsi pemenuhan kebutuhan industri keuangan, dalam kaitannya dengan produksi fatwa tentang produk bank syariah di Indonesia.

Kedua, adanya dan tumbuhnya pandangan economic-determinism di kalangan ulama pada Majelis Ulama Indonesia. Hal ini terungkap dari argumentasi yang diajukan oleh K.H. Ma'ruf Amin dalam sebuah tulisannya, Fatwa and the Development of Sharia Financial Industry: A Lesson from Indonesia, dimana menurutnya pentingnya umat Islam di Indonesia menguasai peredaran uang, dan digunakan untuk sepenuh-penuhnya pada kemaslahatan umat. ${ }^{8} \mathrm{Hal}$ ini menguatkan bahwa nalar pragmatisme adalah sebuah fakta, dan diterapkan pada setiap opini yang dirumuskan oleh MUI. Dalam kaitannya dengan hal tersebut, dua fakta teoritis ini memunculkan satu pertanyaan penting, yang akan dijawab pada artikel ini, yakni: "Bagaimana sesungguhnya manifestasi nalar pragmatisme hukum pada produk fatwa yang difabrikasi oleh DSN MUI?" Merujuk pertanyaan ini, maka artikel ini difokuskan untuk mengkaji bentuk nalar pragmatisme di balik fatwa DSN MUI tentang pelbagai produk bank syariah di Indonesia. Dalam melakukan analisis, penting mengeksplorasi bagaimana pragmatisme hukum dibahas oleh para sarjana hukum Islam. Ada banyak sarjana yang mengkaji isu

${ }^{7}$ Ma'ruf Amin, "Fatwa and The Development of Islamic Financial Industry: A Lesson From Indonesia," Al-Iqtishad: Journal of Islamic Economics 9, no. 2 (2017): h. 331, https://doi.org/10.15408/aiq.v9i2.5353.

${ }^{8}$ Amin, "Fatwa and The Development of Islamic Financial Industry: A Lesson From Indonesia." 
ini, dari ulama generasi tabi'it tabi'in hingga sarjana kontemporer seperti Ahmed Fekry Ibrahim.

Adalah Ahmed Fekry Ibrahim yang membahas secara mendalam terkait konsep pragmatisme dalam hukum Islam. Dalam hal ini, ada beberapa konsep yang ditawarkan. Diantaranya, pragmatisme dapat diidentifikasi dari sesuatu produk, baik pilihan maupun produk hukum seperti sebuah fatwa. ${ }^{9}$ Ini menegaskan bahwa pragmatisme adalah tipologi dari nalar hukum yang ada dibalik sebuah opini hukum. Hal ini tentu berlaku juga dalam hukum Islam. Adapun nalar pragmatisme dapat juga diidentifikasi dari produk dari istinbath hukum Islam, yakni fatwa yang diproduksi oleh ulama. Ini artinya pragmatisme dapat diidentifikasi dari setting dimana sebuah fatwa diproduksi.

Ahmed Fekry Ibrahim meyakini bahwa umumnya para fuqaha' menerima nalar pragmatisme sebagai bagian inheren dalam ijtihad dan memproduksi opini hukum. ${ }^{10}$ Pragmatisme sendiri ditandai dengan orientasi nalar hukum pada utilitarian, manfaat dan kemaslahatan ketika sebuah opini hukum, atau fatwa diperkenalkan. Dalam hal ini, Fauziah Nurdin memahami bahwa pragmatisme meyakini suatu kebenaran didasarkan pada apakah sesuatu berdaya guna, bermanfaat meskipun bersifat relatif. ${ }^{11}$ Makna pragmatisme semacam ini, agak berbeda dengan kebenaran dalam tradisi Islam, yang bersifat absolut, dan bersumber dari wahyu Tuhan. Bukan didasarkan pada analogi rasional manusia. ${ }^{12} \mathrm{Hal}$ ini sejalan dengan pengertian pragmatisme, sebagaimana yang diutarakan oleh Mangun Harjana, dimana ia berasal dari bahasa Yunani, yakni "pramatikos," dimana Pragma berarti tindakan, dengan tikos bermakna paham. Sehingga pragmatisme bermakna: "cakap dan berpengalaman dalam urusan hukum, perkara negara dan dagang". Sedangkan dalam Bahasa Inggris, istilah ini disebut pragmatic yang berarti hal yang berkaitan dengan sesuatu yang bersifat praktis, bukan teoritis dan ide dimana hasilnya dapat dimanfaatkan langsung berhubungan dengan tindakan konkrit bukan spekulatif ataupun abstraksi. ${ }^{13}$ Satu hal yang dapat dipahami dari konsepsi ini, bahwa pragmatisme niscaya mengandaikan adanya satu karakteristik yang berorientasi pada yang bersifat praktis, dan bermanfaat secara langsung. Lantas, bagaimana pragmatisme sebagai sebuah konsepsi dimaknai dalam tradisi Islam?

Carles S. Pierce, William James dan John Dewey sepakat bahwa pragmatisme yang mereka tawarkan sama-sama bermuara pada nilai kebenaran yang bersipat praktis, fungsional, azas manfaat dan berjalan atas dasar metode

\footnotetext{
${ }^{9}$ Ibrahim, Pragmatism in Islamic Law: A Social and Intellectual History, h. 179.

${ }^{10}$ Ibrahim, h. 88.

${ }^{11}$ Fauziah Nurdin, "Kebenaran Menurut Pragmatisme Dan Tanggapannya Terhadap Islam," Jurnal Ilmiah Islam Futura Vol. 13, no. 2 (2014), h. 184.

${ }^{12}$ Nurdin, h. 184.

${ }^{13}$ Nurdin, h. 185.
} 
induktif-empiris. ${ }^{14}$ Sedangkan dalam Islam, pragmatisme juga didasarkan pada nilai-nilai aksiologis yang terimplementasi secara praktis-empiris, dan didasarkan pada fondasi maqashid syari'ah, dimana salah satunya adalah azas kemaslahatan. Dalam hal ini, memahami pragmatisme dalam Islam, khususnya hukum Islam, maka mesti merujuk pada grand theories seperti Istihsan Imam Abu Hanifah, Maslahat Mursalab Imam Malik, Maqashid Syariah Imam Syatibhi, dan Tattabbu ar-Rukhsah Imam Syafi'i. Adapun istihsan sebagaimana yang diperkenalkan dalam mazhab Hanafiyah, merupakan transformasi dalil yang kuat dan berpegang ke dalil yang bersifat samar atau khafi, dengan tujuan agar dapat lebih baik hasilnya.

Muhammad Abu Zahrah menukilkan definisi yang dikemukakan oleh Imam Mazhab, dimana Abu Hasan al-Karghy mendefinisikan istibsan sebagai proses dimana mujtahid menetapkan hukum atas satu masalah dengan meninggalkan wajh atau dalil yang kuat. Definisi ini menurut ulama Hanafiyah, adalah konsep yang paling jelas dan konkrit. ${ }^{15}$ Istihsan sebagai sebuah metode istinbath, diaplikasikan oleh mazhab Hanafi dan Maliki. Dalam beberapa perdebatan, istihsan didefinisikan oleh sarjana Maliki dalam redaksi yang berbeda-beda. Misalnya Ibnu Al-Arabi memaknai bahwa isitibsan meninggalkan satu dalil, untuk berpegang pada dalil yang berlawanan dengan dalil yang pertama. ${ }^{16}$ Kendati demikian meninggalkan dalil, bukan serta merta, melainkan ada dasar argumentasi mengapa satu dalil ditinggalkan (Lihat tabel 1).

Tabel 1. Ilat Istibsan ${ }^{17}$

\begin{tabular}{c|l}
\hline & Karena alasan yang bersipat urf; \\
Meninggalkan Satu Dalil, dan Berpegang pada & Karena ïma' \\
Dalilyang kualitasnya lebih rendah & Untuk realisasi maslahat \\
& Untuk memudahkan \\
& Menolak kesulitan atau musaqath. \\
\hline
\end{tabular}

Ibnu Rusyd juga menegaskan hal yang sama, dan lebih sesuai dengan pandangan Ibnu Al-'Arabi ini. Karena menurutnya, perubahan atau yu'dilu dalil karena didorong oleh umumnya aplikasi dalil yang dengan kualitas khafi. Jika tidak, maka akan menyebabkan hukum tidak produktif diterapkan, karena sulit, atau justru bertentangan dengan nilai-nilai kemaslahatan. ${ }^{18}$ Sementara itu, maslahat mursalah merupakan sebuah metode istinbath hukum atau legal theory yang didasarkan pada kemaslahatan yang tidak mendapatkan legalitas khusus dari nash tentang validitasnya atau tidak terdapat pula dalil yang secara tegas dan

\footnotetext{
${ }^{14}$ Nurdin, h. 195.

${ }^{15}$ Muhammad Abu Zahrah, Ushl Al-Figh (Kairo: Dar Fikr al-Araby, n.d.), h. 262.

${ }^{16}$ Abu Zahrah, h. 163.

17 Abu Zahrah, h. 263.

18 Abu Zahrah, h. 263.
} 
jelas menyatakan ketidakvaliditasannya. ${ }^{19}$ Istilah lain dari maslabah mursalah, adalah istislah sebagaimana yang sering diungkapkan oleh Abu Hamid AlGhazali. Beliau pun menyamakan istislab dengan istibsan dalam dimensi, dimana keduanya sama-sama bertumpu pada nalar instrumental dalam menetapkan hukum. Hal ini juga ditemukan dalam qiyas. Sehingga, Al-Ghazali mengkategorikan keduanya ke dalam istilah 'usul al-mafbumah, yakni prinsipprinsip dimana para sarjana Islam mengutamakan imajinasi rasionalnya ketimbang Hadis. ${ }^{20}$ Dalam hal ini, Abu Zahrah menegaskan, sebagaimana merujuk pandangan Imam Malik, bahwa untuk dapat menerapkan maslahah mursalah, diperlukan tiga syarat, yakni: Pertama, kemaslahatan material atau almaslabath al-drati yang akan dipertimbangkan, adalah sesuatu yang didukung oleh maqashid as-syari' dan tidak bertentangan dengan dalil qath'i. Melainkan mutafaqath atau sejalan dengan kemaslahatan yang dituju oleh syari', atau pemilik syariat, yakni Allah swt. Kedua, kemaslahatan tersebut mesti dapat dinalar dan dapat diaplikasikan secara rasional. Ketiga, menerapkan kemaslahatan tersebut mesti dapat menghilangkan kesulitan, dan kemufsadatan. ${ }^{21}$ Konsepsi maslahat almursalah ini berbeda dengan konsepsi maqashid syariah, yang dipopulerkan oleh Imam Syatibi.

Adapun maqashid shariah, secara harfiah bermakna tujuan hukum. Sedangkan terminologinya, maqashid berarti makna dan hikmah yang dikehendaki Tuhan dalam setiap syariat, baik umum, maupun khusus. Ini berguna untuk memastikan maslahat manusia, dan umat Islam. ${ }^{22}$ Imam AsSyatibi, menjelaskan bahwa maqashid syariah adalah konsepsi dimana Allah ta'ala membebani manusia dengan syariat, tujuannya adalah untuk memelihara tujuan syariat itu sendiri yang meliputi realisasi tiga hal, yakni: maqashid-daruriyah; maqashid-hajizah; dan tabsiniyath. ${ }^{23}$ Adapun yang dimaksud maqashid daruriyah, adalah kemaslahatan yang padanya determinan urusan agama dan dunia. Sederhananya, jika kemaslahatan daruriyah tidak terealisasikan, maka kemaslahatan agama dan dunia tak akan mampu direalisasikan pula. Untuk itu, harus diperhatikan dua hal: Pertama, menegakkan rukunnya dan menetapkan kaidah-kaidahnya. Dengan demikian, proses ini dinilai sebagai upaya memelihara seluruh eksistensi yang ada. Kedua, mencegah dan mengatisipasi dari ketidakseimbangan dari realitas yang ada. ${ }^{24}$ Dalam konteks ini, kemaslahatan yang dikategorikan pada hal daruriyah setidaknya ada lima hal, yakni: memelihara

${ }^{19}$ Mohammad Rusfi, "Validitas Maslahat Al-Mursalab Sebagai Sumber Hukum Islam," Al-

'Adalah Vol. 12, no. 1 (2014), h. 66.

${ }^{20}$ Rusfi, h. 66.

${ }^{21}$ Abu Zahrah, Ushl Al-Fiqh, h. 280.

22 Nabila Zatadini and Syamsuri, "Konsep Maqashid Syariah Menurut Al-Syatibi Dan Kontribusinya Dalam Kebijakan Fiskal," Al-Falah: Journal of Islamic Economics Vol. 3, No. 2 (2018), h. 115.

${ }^{23}$ As-Syatibi Imam, Al-Muwafaqath, Vol. II (Kairo: Dar Ibn 'Affan, 1997), h. 17.

${ }^{24}$ Imam, II:, h. 18. 
agama, nyawa, keturunan, harta, dan akal. Sedangkan maqashid-bajiziah, maknanya adalah segala sesuatu yang determinan kepadanya untuk tujuan tawasu' atau eksistensialitas, dan meminimalisir kesempitan, dan ini dapat diidentifikasi dari segala aspek ibadah, adat, muamalah, dan jinayah. ${ }^{25}$ Berbeda dengan tabsinath, maknanya adalah mempertimbangkan segala sesuatu yang dikategorikan baik oleh adat, dan menghindar dari kesempitan pikiran. ${ }^{26}$ Dengan hal ini, maka hukum yang dihasilkan melalui proses ijtihad dapat sepenuhnya memelihara kemaslahatan yang dituju oleh Allah Swt. sebagai pemilik hukum, atau syari'. Bagaimana konsep ini dielaborasi menjadi kerangka atau framework untuk memahami pragmatisme fatwa, yang menjadi objek formal kajian ini?

Kerangka konseptual kajian ini, khususnya berkenaan dengan pragmatisme hukum, dalam hal ini adalah fatwa, sepenuhnya merujuk pada karya Ahmed Fekry Ibrahim, Pragmatism in Islamic Law: A Social and Intellectual History. Beliau dengan gamblang, dan mendalam mengkaji bagaimana pragmatism sebagai sebuah nalar hukum di praktek oleh para qadi di abad ke-19. Khususnya oleh para hakim Mesir di abad ke-17 dan abad ke-18, jauh sebelum Mehmed Ali mempraktekan nalar pragmatisme pada periode Ottoman, yang didominasi oleh pertimbangan tatabbu' al-rukbas. ${ }^{27}$ Dari hal ini, salah satu nalar penting dan menjadi indikator eksistensi pragmatisme hukum adalah upaya dan proses ijtihad yang menjadi tatabu' al-rukhas sebagai pertimbangan dalam memproduksi fatwa, ataupun hukum. Selain itu, adanya talfiq juga meningkat secara eksponensial selama periode Ottoman tersebut. ${ }^{28}$ Selain itu, sejak AsSyatibi mempopulerkan teori maqashid-shariah, sikap eklektisisme adalah sebuah sikap dimana para fuqaba' memilih dan memilah illat sebuah hukum berdasarkan kepentingan teori utilitas Islami, tumbuh dan ter-institusi dengan baik hingga kini. Bahkan terus menerus dikembangkan dalam skala yang luas, tidak hanya sebatas perdebatan fikih tapi dalam disiplin lain pun nalar eklektisisme berbasis maqashid syariah dipraktekkan secara massif, dan sporadis. Demikian, kerangka utama untuk melacak eksistensi eklektisisme-pragmatis pada fatwa DSN MUI, khususnya terkait produk bank syariah, dapat ditelusuri melalui cara berfilsafat dalam memproduksi fatwa, dengan vulgar memilih illat hukum yang sudah ada, dan hanya linier dengan kepentingan sebuah fatwa diproduksi.

Tujuan utama kajian ini ini untuk mengidentifikasi eklektisismepragmatis dalam fatwa DSN MUI terkait produk perbankan syariah. Karena itu, model analisis yang digunakan sebangun dengan model yang diterapkan oleh Ahmed Fekry Ibrahim, dimana ia berusaha mengidentifikasi nalar hukum yang ada dan tumbuh di kalangan ulama mazhab, dan kemudian mengkategorikannya ke dalam beberapa bentuk kriteria, yakni: Pertama, nalar dari istinbath hukum

\footnotetext{
${ }^{25}$ Imam, II:, h. 22.

${ }^{26}$ Imam, II:, h. 22.

${ }^{27}$ Ibrahim, Pragmatism in Islamic Law: A Social and Intellectual History, h. 129.

${ }^{28}$ Ibrahim, h. 130.
} 
yang melibatkan teori takhayyur dan talfiq, yang menjadi fenomena modern dan dipraktekkan secara luas. Kedua, dalam tradisi hukum Islam klasik, selalu ditemukan upaya menghubungkan antara substantive law (furu) dan legal methodology (usul). Hal ini sejatinya, sejalan dengan prinsip legal hermeneutika, dan ini juga dapat dikategorikan sebagai eklektisisme-pragmatis. Ketiga, kalangan reformis hukum Islam, lebih menyukai metode yang bersifat arbitrative, dimana seutuhnya dimotivasi oleh kebijaksaan. ${ }^{29}$ Pada tahap ini kemudian, teori maqashid syariah mendapatkan tempat. Dalam kerangka ini analisis akan dibangun, dan data-data yang dibaca dari kompilasi fatwa DSN MUI terkait produk bank syariah, akan di interpretasi dalam paradigma yang diperkenalkan oleh Ahmed Fekry Ibrahim ini.

\section{Pembahasan}

\section{Fatwa DSN MUI: Tradisi dan Nalar}

Perkembangan produk bank syariah di Indonesia tidak terlepas dari peran penting DSN MUI. Hal ini sejalan dengan kajian yang dilakukan oleh Eja Hardi Armaz, melalui artikelnya "Fatwa DSN MUI dan Perkembangan Produk Perbankan Syariah di Indonesia." Dengan meyakinkan beliau mengutarakan tesis bahwa:

"fatwa terbanyak dikeluarkan oleh DSN-MUI pada tabun 2000 dan 2002 yang merupakan respon cepat MUI untuk memberikan acuan instrument kepatuban syariah. Kepatuban syariah tersebut dituangkan dalam UU No. 10 Tahun 1998 perubahan UU No. 07 Tabun 1992 disebutkan bahwa bank syariah harus menggunakan prinsip-prinsip syariah. Kemudian diksi fatwa dijelaskan dan dicantumkan pada UU No. 21 Tabun 2008. Dilain pibak produk dan jasa yang dikeluarkan oleh bank syariah saat ini telah terakomodir dengan fatwa-fatwa yang dikeluarkan oleh DSN-MUI."

Sederhananya, tesis ini menguatkan pandangan bahwa perkembangan produk perbankan ditopang sepenuhnya oleh terbitnya fatwa DSN MUI. Dalam konteks ini, agaknya penting membedah fatwa DSN MUI terkait produk bank syariah, dan keuangan umumnya. Selain itu, Ma'ruf Amin pernah mengutarakan bagaimana nalar istinbath hukum dan memproduksi fatwa yang diterapkan oleh DSN MUI, dalam satu orasi ilmiah yang disampaikannya pada tahun 2017, di depan Civitas Akademika UIN Maulana Malik Ibrahim.

Menurut Ma'ruf Amin, fatwa-fatwa DSN-MUI yang dikenal luas hari ini mempergunakan solusi hukum (makharij fiqhiyah) sebagai landasannya, dimana setidaknya ada 4 (empat) solusi fikih yang dijadikan landasan dalam menetapkan fatwa DSN-MUI, yaitu: al-Taysir al-Manhaji, Tafriq al-Halal 'an al-Haram, I'adah al-

${ }^{29}$ Ibrahim, h. 7.

${ }^{30}$ Eja Armaz Hardi, "Fatwa DSN MUI Dan Perkembangan Produk Bank Syariah Di Indonesia," An-Nisbab: Jurnal Ekonomi Syariah Vol. 05, no. 2 (2019): h. 82. 
Nadhar, dan Tahqiq al-Manath. ${ }^{31}$ Empat solusi fikih, atau lebih tepat disebut nalar filosofis ini erat hubungannya dengan pragmatisme hukum. Pertanyaannya kemudian adalah: diantara nalar-filosofis yang ada pada fatwa DSN-MUI, mana yang lebih dominan digunakan dan erat hubungannya dengan tradisi filsafat eklektisisme-pragmatis?

Fatwa yang diproduksi oleh DSN MUI bertumbuh dan bertambah seiring perkembangan sosial dan ekonomi di tengah masyarakat. Tercatat hingga tahun 2017, fatwa DSN MUI berjumlah sebanyak 109 fatwa, yang terdiri dari 27 fatwa terkait dengan industri perbankan; Bidang IKNB 10 buah, Bidang Pasar Modal 16 buah, Bidang Bisnis 7 buah, dan Fatwa yang bersifat general sebanyak 45 buah. Berangkat dari data ini, merujuk pada isu penelitian-Fatwa DSN MUI tentang Produk Perbankan Syariah, maka dipilih 25 (dua puluh lima) Fatwa DSN MUI yang terkait dengan produk perbankan syariah. Hanya perlakuan sebagai data terhadap 25 (dua puluh lima) fatwa ini tetap merujuk pada homogenitas pola dan data- "jika pola nalar dua puluh lima fatwa ini seragam, maka merujuk dua hingga tiga fatwa dianggap sebagai representasi, dan sudah mewakili." Fatwa ini diposisikan sebagai data primer, yang kemudian dipotret dan diinterpretasikan sesuai dengan paradigma yang dibangun oleh Ahmed Fikry Ibrahim.

Diantara fatwa yang dimaksud adalah Fatwa DSN Nomor: 92/DSNMUI/IV/2014 tentang Pembiayaan yang disertai Rabn (at-tamwil al-mautsuq bi alrahn). Memperhatikan teks fatwa ini, agaknya dapat dipahami bahwa DSN MUI menerapkan tradisi bilah, sebagaimana yang diyakini oleh Elimartati. Metode ini didefinisikan oleh Ibnu Qayyim al-Jauziyah sebagai nalar khusus yang menyebabkan hukum mengalami perubahan dari satu keadaan kepada keadaan lainnya. ${ }^{32}$ Salah satu dari karakter bilah yang dapat ditangkap dari produksi dan legislasi hukum Islam, adalah eksistensi perubahan yang ada pada substansi hukum syar'i atas persoalan dan kemudian digunakan untuk kondisi lain dengan tujuan menetapkan kebenaran atau menolak kezaliman. Ini dilakukan karena diyakini dapat memelihara kemaslahatan syar'i. ${ }^{33}$ Selain itu, nalar taysir al-manhaji sebagai upaya memilih pendapat yang ringan namun tetap sesuai aturan, juga dominan diterapkan pada fatwa DSN-MUI tentang at-tamwil al-mautsuq bi al-rabn. Hal ini dapat ditelusuri dari beberapa teks sebagai berikut: Pertama, pada konsideran menimbang disebutkan, pada butir (a) bahwa fatwa-fatwa DSN-MUI terkait rahn dipandang belum mengakomodasi pengembangan usaha berbasis rahn, (b) bahwa lembaga Keuangan Syariah memerlukan fatwa terkait

${ }^{31}$ Ma'ruf Amin, "Solusi Hukum Islam (Makharij Fiqhiyyah) Sebagai Pendorong Arus Baru Ekonomi Syariah Di Indonesia: Kontribusi Fatwa DSN-MUI Dalam Peraturan RI" (Malang: UIN Maulana Malik Ibrahim, 2017), h. 7.

32 Elimartati, "Analisis Metode Hilal Dalam Proses Fatwa DSN-MUI," Jurnal Ilmiah Syari'ah Vol. 15, No. 1 (2016): h. 77.

33 h. 79. 
pengembangan usaha berbasis Rahn. ${ }^{34}$ Dua butir ini menegaskan illat atau alasan empiris mengapa fatwa ini diproduksi, dan sepenuhnya menegaskan eksistensi eklektisisme-pragmatis dalam fatwa ini.

Fatwa ini menjadi Quran; Hadis dan Ijma' sebagai dalil hukum. Dimana Q.S. Al-Baqarah: 283, yang menegaskan: "dan apabila kamu dalam perjalanan sedang kami tidak memperoleh seorang juri tulis maka hendaklah ada barang tanggungan yang dipegang." Serta Q.S. Al-Maidah: 1, yang bermakna: "hai orang yang beriman! Tunaikan lah akad-akad itu". Juga Q.S. Al-Isra': 34, dimana dinyatakan: "dan tunaikan lah janji-janji itu, sesungguhnya janji itu akan dimintai pertanggungjawaban." Sedangkan Hadis Nabi yang diriwayatkan oleh al-Bukhari dan Muslim dari Aisyah ra, diutarakan bahwa: "Sesungguhnya Rasulullah saw pernah membeli makanan dengan berutang dari seorang Yahudi dan Nabi menggadaikan sebuah baju besi kepadanya." Sedangkan Ijma' merujuk pada pendapat ulama yang ada pada kita Wahbab al-Zuhaili, al-Fiqh al-Islam wa Adilatubu. Dimana disebutkan bahwa para ulama sepakat membolehkan akad Rahn. Melengkapi dalil hukum, fatwa ini juga mengutip kaidah fikih, yang menegaskan bahwa: "Pada dasarnya segala bentuk mu'amalat boleh dilakukan kecuali ada dalil yang mengharamkannya." 35 Sedangkan pendapat ulama yang dipilih, dan dijadikan fondasi argumentasi hukum dapat dilihat dari Tabel. 2 berikut ini:

Tabel 2. Pendapat Ulama tentang Rabn

\section{Ulama Pendapat tentang Rahn}

Ibnu Qudamah 'Mengenai dalil ijma' umat Islam sepakat (ijma') bahwa secara garis besar akad rahn (gadai/penjaminan utang) diperbolehkan."

Al-Khathib Al"Pemberi gadai boleh memanfaatkan barang gadai Syarbini secara penuh dengan syarat tidak mengakibatkan berkurangnya (nilai) barang gadai tersebut."

Dalam fatwa lainnya juga ditemukan pola, dan nalar yang sama, yakni dengan merujuk dalil fikih (seperti Quran; Hadis; Ijma' dan kaidah fikih), dan membentangkan pandangan ulama untuk mendukung tujuan fatwa. Misalnya Fatwa DSN-MUI Nomor: 119/DSN-MUI/II/2018 tentang Pembiayaan Ultra Mikro (al-tamwil lil al-bajah al-mutanabiyat al-shughra) berdasarkan prinsip syariah. Fatwa ini juga mempertimbangkan, bahwa di antara pelayanan jasa keuangan

${ }^{34}$ DSN-MUI, "Fatwa Dewan Syariah Nasional Tentang Pembiayaan Yang Disertai Rahn,” Pub. L. No. DSN-MUI No. 92/DSN-MUI/IIV/2014, 92/DSN-MUI/IIV/2014 (2014), h. 1.

\footnotetext{
35 h. 2.

${ }^{36}$ h. $2-3$.
} 
yang dibutuhkan masyarakat adalah pembiayaan ultra mikro yang meliputi pembiayaan untuk pembelian objek berupa barang yang beragam (multi barang) dan objek berupa jasa yang beragam (multi jasa). Selain itu, juga disebutkan bahwa Lembaga Keuangan Syariah perlu merespon kebutuhan masyarakat yang berkaitan dengan pelayanan jasa keuangan. ${ }^{37}$ Dalam proses istidlal, atau pengungkapan dalil, selain merujuk pada syariat sebagai sumber hukum (seperti Quran; Hadis; Ijma' dan Kaidah Fikih), juga mengemukakan teori yang ada pada al-Ma'ayir al-Syar'iyyah AAOIFI tentang Dhabit al-Gharar al-Mufsid lil Muamalat alMaliah, yakni:

"Transksi jual beli itu boleh dengan harga yang ada unsur ghararnya tetapi gharar yang ditolerir seperti jual beli dengan harga tertentu untuk sejumlah barang yang bisa dilibat, tetapi tidak diketahui berapa jumlah dan harga totalnya, seperti menjual sejumlah biji-bijian yang biasanya dijual setiap kilogram dengan harga sekian."38

Dari teori Dhabit al-Gharar al-Mufsid lil Muamalat al-Maliah yang termaktub pada al-Ma'ayir al-Syar'iyyah AAOIFI, menegaskan adanya asas utilitas dan menjadi manifestasi dari eklektisisme-pragmatis. Selain itu, sikap memilih sesuai dengan core interest yang ingin dibela melalui fatwa DSN-MUI ini dapat diidentifikasi dari pengutipan pendapat ulama terkait akad mu'allaq seperti: 1) jumhur ulama Hanabilah yang berpendapat bahwa akad ta'alluq tidak boleh diterapkan setiap akad al-tamlikah baik yang bersifat pertukaran atau al-mu'awdhat maupun tidak atau al-tabarru'at, baik yang dipindahkan kepemilikannya itu bendanya (al-a'yan) maupun manfaatnya, termasuk pertukaran selain harta (almubadalat ghair al-maliyyah), 2) Ibn Taimiyah dan Ibn Qayyim al-Jauziyah alHanbali membolehkan akad mu'allaq atas seluruh akad tanpa pengecualian mulai dari akad al-tamlikat, faskh, tabarru'at, kewajiban (iltizamat), baik yang termasuk akad jual-beli, ijarah, kafalah, hibah, rahn, ibra' dan yang lainnya bahkan akad nikah. ${ }^{39}$ Berangkat dari dalil, teorema fikih ini, maka fatwa DSN-MUI Nomor: 119/DSN-MUI/II/2018 berhasil dirumuskan dan menjadi alternatif hukum baru.

Demikian dapat diidentifikasi dari premis hukum yang dihasilkan, dan ada indikator perumusan adalah bentuk kompromis antara prinsip eklektisismepragmatis hukum. Misalnya terkait ketentuan akad yang ditegaskan bahwa: "pembiayaan Ultra Mikro Multi-barang boleh dilakukan dengan menggunakan akal jual beli, akad jual-beli murabahah, akad jual beli salam, akad jual beli istishna', akad ijarah, atau akad ijarah muntabiyyah bi al-tamlik dengan ketentuan: 1) jika menggunakan akad jual-beli murabahah, maka wajib tunduk dan patuh pada

${ }^{37}$ DSN-MUI, "Fatwa DSN-MUI Tentang Pembiayaan Ultra Mikro (al-Tamwil Lil alHajah al-Mutanahiyat al-Shughra) Berdasarkan Prinsip Syariah.," Pub. L. No. 119/DSNMUI/II/2018 (2018), h. 1.

${ }^{38}$ h. 4.

${ }^{39}$ h. $4-5$. 
ketentuan (dhawabith) dan batasan (budud) yang terdapat dalam fatwa DSN-MUI Nomor: 110/DSN-MUI/IX/2017 tentang akad jual beli; 2) Jika menggunakan akad jual-beli murabahah, maka wajib tunduk dan patuh pada ketenttan (dhawabith) dan batasan (budud)yang terdapat dalam fatwa DSN-MUI nomor 04/DSN-MUI/IIV/2000 tentang Murababah; 3) Jika menggunakan akad jualbeli istishna' dan/atau istishna' paralel, maka wajib tunduk dan patuh pada ketentuan (dhawabith) dan batasan (hudud) yang terdapat dalam fatwa DSNMUI Nomor. 06/DSN-MUI/IIV/2000 tentang jual-Beli Istishna' dan fatwa DSN-MUI Nomor: 22/DSN-MUI/III/2002 tentang Jual-Beli Istishna' Paralel. ${ }^{40}$ Bagaimana tradisi dan nalar diinterpretasikan kembali, dan dihubungkan dengan eklektisisme-pragmatis hukum yang dibahas oleh Ahmed Fekry Ibrahim? Untuk menjawab pertanyaan ini, agaknya perlu melakukan verifikasi teoritis atas data tersebut, sehingga didapat penjelasan teoritis yang gamblang atas tradisi dan nalar pada fatwa DSN-MUI tentang produk perbankan syariah di Indonesia.

\section{Fatwa DSN-MUI dan Eklektisisme-Pragmatis Hukum}

Satu tesis yang dapat diajukan dalam tulisan ini, bahwa: "meskipun ekonomi Islam dan turunannya dipercaya sebagai purifikasi atas kapitalisme. Namun, vested-interest dan anasir-anasir pembelaan terhadap kepentingan bisnis adalah bagian yang inheren dalam Islam itu sendiri." Hal ini memperkuat tesis yang sebelumnya telah ditawarkan oleh Aisalkyn Botoeva, dimana menurut beliau: "ekonomi Islam dipopulerkan melalui kombinasi berbagai faktor seperti gerakan anti-kolonial, pembaharuan religiusitas global, dan aktivitas strata sosial baru yang memicu munculnya keshalehan dengan orientasi kapitalistik." ${ }^{41}$ Kedua tesis ini menjadi fondasi yang meyakinkan bahwa implementasi filsafat eklektisisme-pragmatis pada fatwa DSN-MUI tentang produk perbankan syariah di Indonesia, disamping didorong oleh upaya ideal tapi juga dapat diartikan sebagai "serving the market needs" yang diminta oleh industri keuangan syariah yang terus tumbuh di Indonesia. Permasalahan yang disorot tentu bukan pada nalar pasar yang mendorong fatwa diproduksi, melainkan pada akar bagaimana eklektisisme-pragmatis yang ada pada fatwa berakar pada tradisi hukum Islam klasik.

Nalar eklektisisme-pragmatis pada fatwa DSN-MUI bukanlah hal yang baru. Tapi sebagai sebuah teori dan praktek, nalar ini dapat ditemukan sepanjang perkembangan hukum Islam klasik. Dalam hal ini Ahmed Fekry Ibrahim memperkenalkan bahwa konsepsi hukum Islam merujuk pada integrasi antara furu' atau substantive law, usul al-fiqh atau legal methodology, dan fiqh (jurisprudence). ${ }^{42}$ Kompleksitas hukum Islam seperti ini memungkinkan munculnya nalar

\footnotetext{
${ }^{40}$ h. 6-7.

${ }^{41}$ Aisalkyn Botoeva, "Islam and the Spirits of Capitalism: Competing Articulations of the Islamic Economy,” Politics \& Society Vol. 46, No. 2 (2018): h. 235.

${ }^{42}$ Ibrahim, Pragmatism in Islamic Law: A Social and Intellectual History, h. 6.
} 
pragmatis dalam perkembangannya. Kemungkinan ini, kini menjadi empiris. Hal ini dapat dipahami dari tesis yang dikemukakan oleh Jeremy Bentham, bahwa hukum mesti berfondasi pada setidaknya 8 (delapan) aspek, yakni: 1) In respect to its source; 2) In respect to the quality of its Subject; 3) In Respect to its Object; 4) In respect to its extent; 5) In respect to its aspect; 6) in respect to its force; 7) in respect to its expression; 8) in respect to its remedy appendages. ${ }^{43}$ Dari respon hukum terhadap 8 (delapan) hal ini, maka legislasi sebuah hukum setidaknya memuat 3 (tiga) prinsip, yakni: prinsip manfaat, asketik dan prinsip sewenang-wenang. Adapun prinsip manfaat, hukum dibuat selalu didasarkan pada manfaat publik sebuah peraturan. Sementara prinsip asketik, bertujuan membatasi agar hukum tidak selalu memberikan kesenangan, melainkan menuntut adanya pengorbanan publik. Sedangkan terakhir, prinsip sewenang-wenang bermakna bahwa baik dan buruk diukur berdasarkan kesenangan sekelompok orang yang membuat aturan, bukan bagi objek yang dikenakan peraturan itu. ${ }^{44}$ Dalam kerangka ini, eklektisisme pragmatis fatwa sebagai sebuah legislasi atas produk perbankan di Indonesia dapat dimaknai.

Dalam konteks hukum Islam, nalar eklektisisme-pragmatis dapat dilacak dari beberapa hal: Pertama, pemilihan atas dalil yang mendukung tujuan sebuah fatwa dirumuskan; Kedua, adanya indikasi memenuhi permintaan, baik publik maupun korporat; dan Ketiga, adanya upaya melakukan proteksi terhadap kepentingan umat, sekaligus korporat. Ketiga konsep ini sejatinya ditemukan pada prinsip legislasi hukum Islam, klasik maupun kontemporer. Misalnya istibsan Imam Abu Hanifah; maslabah mursalah Imam Malik; dan qaul qadim-qaul jadid Imam Syafi'i. Mengapa metode penalaran ini dinilai sebagai kerangka dimana di dalamnya mengandung filsafat eklektisisme-pragmatis? Karena penalaran hukum yang ditawarkan oleh ketiga imam ini, sejatinya adalah wujud terhadap pembelaan terhadap prinsip-prinsip utilitarianisme-Islami.

Sementara itu, Yudarwin melalui kajiannya yang cukup mendalam mencoba menemukan makna penting eklektisisme-pragmatis hukum Islam melalui penelusuran terhadap akar kata eklektisisme, dimana menurutnya kata tersebut berasal dari Bahasa Yunani, eklekticos; eklegein yang artinya memilih. Dari hal itu, maka eklektisisme diartikan sebagai: the method or system of an eclectic, atau metode untuk pilihan dari beberapa sumber. ${ }^{45}$ Jadi, ketika kata ini disandingkan dengan pragmatis, maka istilah eklektisisme-pragmatis dapat diartikan sebagai proses pemilihan pendapat dan dalil hukum yang didasarkan para penalaran pragmatis, dengan tujuan dapat membela kepentingan dibalik produk hukum tersebut. Dalam bahasa Arab, eklektisisme disebut dengan talfiq yang artinya

\footnotetext{
${ }^{43}$ Jeremy Bentham, Principles of Legislation (London: The Athlone Press, 1970), h. 1.

${ }^{44}$ Bentham, h. 10.

45 Yudarwin, "Eklektisisme Antara Hukum Islam Dan Hukum Umum: Studi Kritis Atas Gagasan Abmad Qodri Aziay Dalam Mewujudkan Hukum Nasional' (Tesis: Medan, Pascasarjana UIN Sumatera Utara, 2016), h. 32.
} 
mengamalkan lebih dari satu pendapat (mazhab) yang dianggap baik. ${ }^{46}$ Hanya saja dalam beberapa penilaian, talfiq atau eklektisisme terkadang dinilai, bahkan dihindari oleh beberapa kalangan. Karena terkesan mencari bilah atau alasan untuk menghindar dari taklif-hukum yang memberatkan. Untuk itu, Al-Alai (w.761) mengajukan syarat untuk mempraktekan talfiq, yakni: Pertama, pendapat yang dikemukakan oleh mazhab lain tersebut dinilai lebih ibtiyath atau hati-hati dalam menjalankan agama; Kedua, dalil dari pendapat yang dikemukakan mazhab itu dinilai kuat dan rajib ${ }^{47}$ Qodri Azizy mencoba me-reformulasi ulang gagasan al-Alai tersebut dengan mengajukan satu tesis bahwa talfiq dapat dan boleh dilakukan selama dalam bingkai doktrin keagamaan dalam Islam. Mengambil suatu doktrin atau pemikiran mazhab atau mujtabid tertentu, dan itupun harus memenuhi kriteria tertentu yang dibolehkan. ${ }^{48}$ Dari berbagai teori ini, dapat ditarik satu tesis bahwa talfiq atau eklektisisme dalam penalaran hukum Islam, tentu tujuannya, salah satunya adalah membela kepentingan di balik sebuah fatwa dibuat, baik publik maupun korporat.

Dalam locus yang dibahas di atas, pandangan ini dapat ditelusuri dari teori Ahmed Fekry Ibrahim yang menyebutkan bahwa praktek eklektisisme seutuhnya untuk merealisasikan tujuan pragmatis ${ }^{49}$ — utilitas; dan interest yang ada di balik fatwa dibuat. Dalam berbagai manhaj, pragmatis ini ditemukan dalam berbagai manifestasi dan implementasi, terutama dalam pluralisme hukum atau istinbath hukum yang melibatkan dalil-dalil yang kompleks, dari berbagai mashab. Hanya saja tidak semua proses legal-pluralisme ini yang bersifat pragmatis. Adakalanya bersifat non-pragmatis. Misalnya Al-Subki dan Al-Zarkashi, dapat dikategorikan sebagai ulama yang pragmatis dalam berhadapan dengan legal-pluralisme. Tetapi dalam isu-isu lainnya, keduanya justru bersifat non-pragmatis. Sedangkan AlGhazali dan al-Shatibi, terkenal sebagai dua fuqaba' yang menentang pandangpandan eklektisisme-pragmatis dalam fikih. Sehingga, keduanya memperkenalkan teori kemaslahatan publik atau maslahab. ${ }^{50}$ Kendati demikian, teori maslabah yang diperkenalkan oleh dua fuqaba' ini, kemudian menjadi bentuk baru dari praktek eklektisisme-pragmatis dalam legislasi hukum Islam. Termasuk dalam proses produksi fatwa. Tak terkecuali fatwa DSN-MUI tentang produk perbankan syariah di Indonesia. Dari seperangkat teori ini, maka tesis umum yang dapat diajukan pada artikel ini, terkait dengan fatwa DSN-MUI tentang produk perbankan syariah adalah: Pertama, penalaran eklektisisme-pragmatis pada Fatwa DSN MUI tentang produk perbankan syariah dapat dilacak dari pemilihan dalil hukum yang bersifat konsisten pada dalil-dalil primer, namun bersifat fleksibel dalam memilih dalil-dalil sekunder-pandangan para ulama.

\footnotetext{
${ }^{46}$ h. 33.

47 h. 34.

48 h. 34.

${ }^{49}$ Ibrahim, Pragmatism in Islamic Law: A Social and Intellectual History, h. 3.

${ }^{50}$ Ibrahim, h. 3-4.
} 
Kedua, adanya prinsip proteksi terhadap kebutuhan karporat, dalam hal ini mendorong industri perbankan merespon kebutuhan pasar, sehingga fatwa dibuat dalam rangka kepentingan tersebut. Tesis ini dapat dikonfirmasi melalui teorisasi solusi fikih yang disampaikan oleh Ma'ruf Amin dalam orasi ilmiahnya pada Universitas Islam Negeri Maulana Malik Ibrahim, tahun 2017.

Ma'ruf Amin menyebutkan setidaknya ada 4 (empat) landasan dalam menetapkan fatwa DSN-MUI, yakni: Pertama, "al-taysir al-manbajz", yang bermakna memilih pendapat yang ringan namun tetap sesuai aturan. Meskipun pengambilan pendapat yang lebih ringan atau at-taisir, namun tetap dalam kerangka manhaj yang ada. Maknanya, fatwa DSN-MUI adalah wahana solusi terbaik selama tidak bertentangan dengan syariah. Tetapi, metode ini tidak boleh berlebihan atau al-mubalaghah fi al-taysir. Sebab jika ini dilakukan, maka akan bermuara pada sikap al-tasabul atau meremehkan. Dalam prakteknya, metode tanpa mengikuti kaidah fikih yang ada secara metodologi. Dimana, tidak jarang suatu masalah dijawab dengan fatwa yang meringankan namun hanya mempertimbangkan aspek kemaslahatan per se dan tidak mengindahkan al-manhaj yang populer. Ini dihindari, dalam pembuatan fatwa DSN-MUI karena dikategorikan semata-mata tatabbu' al-rukhash. Secara sederhana, metode al-taysir al-manhaji adalah: "menggunakan pendapat yang lebih rajih dan lebih maslahat jika memungkinkan. Jika tidak, maka yang digunakan adalah pendapat yang lebih maslahat (saja)". Penerapannya, dengan menerapkan dua pandangan, yakni pandangan substantif yang menjadikan tujuan atau hasil akhir dan isi (al-maqashid wa al-ma'ani) sebagai ugeran dalam menentukan hukum, dan pandangan legal formal yang menggunakan kata atau kalimat dalam bentuk (al-alfarb wa al-mabani) sebagai ugeran dalam menentukan hukum. ${ }^{51}$ Kedua, penalaran dengan memisahkan antara halal dan non-halal. Umumnya, sarjana memahami bahwa percampuran antara halal dan yang haram, maka dimenangkan yang haram, sesuai dengan kaidah "apabila bercampur antara yang halal dan yang haram, maka percampuran tersebut dihukum haram" (idza ijtima' al-halal wa al-haram qhuliba al-haram). Ini tidak sepenuhnya tepat diterapkan pada bidang ekonomi, kecuali dalam bidang pangan atau konsumsi. ${ }^{52}$ Dalam bidang ekonomi, kaidah yang tepat digunakan adalah tafriq baina al-halal 'ani al-haram, atau pemisahan yang halal dari yang haram. Dalam implementasinya, setiap pendapatan dari usaha yang halal maka dapat diklaim sebagai asset, sedangkan dari yang non-halal atau underground economy maka dapat digunakan untuk kepentingan umum. Wujud konkritnya adalah pendirian unit usaha syariah (UUS) oleh Bank Konvensional.

Ketiga, kaidah i'adah al-naz̧har atau penelaahan ulang. Telaah ulang terhadap pendapat ulama terdahulu bisa dilakukan dalam hal pendapat ulama terdahulu dianggap tidak cocok lagi untuk dipedomani karena faktor sulit

51 Amin, "Solusi Hukum Islam (Makharij Fiqhiyyah) Sebagai Pendorong Arus Baru Ekonomi Syariah Di Indonesia: Kontribusi Fatwa DSN-MUI Dalam Peraturan RI," h. 8.

52 Amin, h. 10. 
diimplementasikan (ta'assur, ta'ad₹dzur aw shu'ubah al-amal). Telaah ulang salah satunya caranya dilakukan dengan menguji kembali pendapat yang mu'tamad dengan mempertimbangkan pendapat hukum yang selama ini dipandang lemah (marjuh bahkan mabjur), karena ada ilath hukum yang baru atau pendapat tersebut lebih membawa maslahat; kemudian pendapat tersebut dijadikan pedoman atau mu'tamad dalam menetapkan hukum. ${ }^{53}$ Penalaran ini banyak ditemukan pada akad sewa-menyewa, dan kafalah bil ujrah. Terakhir adalah penalaran tahqiq almanath atau analisa penentuan alasan dan illat. Penalaran ini untuk mengetahui adanya alasan hukum lain dalam satu kasus, selain illat yang diketahui sebelumnya, baik melalui nash, ijma' ataupun istinbath. ${ }^{54}$ Jika dicermati, tradisi penalaran hukum Islam pada DSN-MUI ini, menjadi fondasi dari praktek eklektisisme-pragmatis. Pandangan inilah yang menjadi dasar dari tesis yang diajukan sebelumnya.

\section{Penutup}

Mengulang tesis yang diajukan sebelumnya, bahwa: "meskipun ekonomi Islam dan turunannya dipercaya sebagai purifikasi atas kapitalisme. Namun, vested-interest dan anasir-anasir pembelaan terhadap kepentingan bisnis adalah bagian yang inheren dalam Islam itu sendiri". Hal ini memperkuat tesis yang sebelumnya telah ditawarkan oleh Aisalkyn Botoeva, dimana menurut beliau: "ekonomi Islam dipopulerkan melalui kombinasi berbagai faktor seperti gerakan anti-kolonial, pembaharuan religiusitas global, dan aktivitas strata sosial baru yang memicu munculnya keshalehan dengan orientasi kapitalistik." Kedua tesis ini menjadi fondasi yang meyakinkan bahwa implementasi filsafat eklektisismepragmatis pada fatwa DSN-MUI tentang produk perbankan syariah di Indonesia, disamping didorong oleh upaya ideal tapi juga dapat diartikan sebagai "serving the market needs" yang diminta oleh industri keuangan syariah yang terus tumbuh di Indonesia. Permasalahan yang disorot tentu bukan pada nalar pasar yang mendorong fatwa diproduksi, melainkan pada akar bagaimana eklektisisme-pragmatis yang ada pada fatwa berakar pada tradisi hukum Islam klasik. Inilah kesimpulan utama, atau tesis utama yang dapat dihasilkan pada artikel ini. Dengan demikian, maka kajian ini dapat merumuskan dua teori penting, yakni: Pertama, penalaran eklektisisme-pragmatis pada Fatwa DSN MUI tentang produk perbankan syariah dapat dilacak dari pemilihan dalil hukum yang bersifat konsisten pada dalil-dalil primer, namun bersipat fleksibel dalam memilih dalil-dalil sekunder-pandangan para ulama. Kedua, adanya prinsip proteksi terhadap kebutuhan korporat, dalam hal ini mendorong industri perbankan merespon kebutuhan pasar, sehingga fatwa dibuat dalam rangka kepentingan tersebut.[]

${ }^{53}$ Amin, "Fatwa and The Development of Islamic Financial Industry: A Lesson From Indonesia," h. 13.

${ }^{54}$ Amin, h. 14. 


\section{Daftar Pustaka}

Abu Zahrah, Muhammad. Ushl Al-Fiqh. Kairo: Dar Fikr al-Araby, n.d.

Amin, Ma'ruf. "Fatwa and The Development of Islamic Financial Industry: A Lesson From Indonesia." Al-Iqtishad: Journal of Islamic Economics 9, no. 2 (2017): 331-350. https://doi.org/10.15408/aiq.v9i2.5353.

_. "Solusi Hukum Islam (Makharij Fiqhiyyah) Sebagai Pendorong Arus Baru Ekonomi Syariah Di Indonesia: Kontribusi Fatwa DSN-MUI Dalam Peraturan RI.” UIN Maulana Malik Ibrahim, 2017.

Armaz Hardi, Eja. "Fatwa DSN MUI Dan Perkembangan Produk Bank Syariah Di Indonesia." An-Nisbab: Jurnal Ekonomi Syariab Vol. 05, no. 2 (2019).

Bentham, Jeremy. Principles of Legislation. London: The Athlone Press, 1970.

Botoeva, Aisalkyn. "Islam and the Spirits of Capitalism: Competing Articulations of the Islamic Economy." Politics \& Society Vol. 46, no. 2 (2018).

DSN-MUI. Fatwa Dewan Syariah Nasional tentang Pembiayaan yang Disertai Rahn, Pub. L. No. DSN-MUI No. 92/DSN-MUI/IIV/2014, 92/DSNMUI/IIV/2014 (2014).

- Fatwa DSN-MUI tentang Pembiayaan Ultra Mikro (al-tamwil lil alhajah al-mutanahiyat al-shughra) berdasarkan prinsip syariah., Pub. L. No. 119/DSN-MUI/II/2018 (2018).

Elimartati. “Analisis Metode Hilal Dalam Proses Fatwa DSN-MUI." Jurnal Ilmiah Syari'ah Vol. 15, no. 1 (2016).

Ibrahim, Ahmed Fekry. Pragmatism in Islamic Law: A Social and Intellectual History. New York: Syracuse University Press, 2015.

Imam, As-Syatibi. Al-Muwafaqath. Vol. II. Kairo: Dar Ibn 'Affan, 1997.

Nurdin, Fauziah. "Kebenaran Menurut Pragmatisme Dan Tanggapannya Terbadap Islam.” Jurnal Ilmiah Islam Futura Vol. 13, no. 2 (2014).

Rusfi, Mohammad. "Validitas Maslahat Al-Mursalah Sebagai Sumber Hukum Islam." Al-'Adalah Vol. 12, no. 1 (2014).

Ustman bin Abdurrahman. Adb Al-Mufti Wa Mustafti. Mosul: Maktabah Al-Ulm wa Al-Hukm, 1986.

Yudarwin. "Eklektisisme Antara Hukum Islam Dan Hukum Umum: Studi Kritis Atas Gagasan Ahmad Qodri Azizy Dalam Mewujudkan Hukum Nasional." Pascasarjana UIN Sumatera Utara, 2016.

Zatadini, Nabila, and Syamsuri. "Konsep Maqashid Syariah Menurut Al-Syatibi Dan Kontribusinya Dalam Kebijakan Fiskal." Al-Falah: Journal of Islamic Economics Vol. 3, no. 2 (2018). 